\title{
Human Induced Pluripotent Stem Cells : Clinical Signifi- cance and Applications in Neurologic Diseases
}

\author{
Eun-Ah Chang, ${ }^{1}$ Sung-Won Jin, ${ }^{2}$ Myung-Hyun Nam, ${ }^{1}$ Sang-Dae Kim ${ }^{2}$ \\ Department of Laboratory Medicine,' Korea University Ansan Hospital, Ansan, Korea \\ Department of Neurosurgery, ${ }^{2}$ Korea University Ansan Hospital, Ansan, Korea
}

The generation of human induced pluripotent stem cells (iPSCs) from somatic cells using gene transfer opens new areas for precision medicine with personalized cell therapy and encourages the discovery of essential platforms for targeted drug development. iPSCs retain the genome of the donor, may regenerate indefinitely, and undergo differentiation into virtually any cell type of interest using a range of published protocols. There has been enormous interest among researchers regarding the application of iPSC technology to regenerative medicine and human disease modeling, in particular, modeling of neurologic diseases using patient-specific iPSCs. For instance, Parkinson's disease, Alzheimer's disease, and spinal cord injuries may be treated with iPSC therapy or replacement tissues obtained from iPSCs. In this review, we discuss the work so far on generation and characterization of iPSCs and focus on recent advances in the use of human iPSCs in clinical setting.

Key Words : Cell-based therapy · Induced pluripotent stem cells · Precision medicine.

\section{INTRODUCTION}

Stem cells exhibit the capacity of self-renewal and may undergo differentiation into various tissue types. These are divided into pluripotent stem cells (PSCs; embryonic stem cells [ESCs] and induced pluripotent stem cells [iPSCs]) and multipotent stem cells (adult stem cells [ASCs]) based on their differentiation capacity ${ }^{45}$. PSCs, including ESCs derived from embryos and iPSCs derived by gene transfer, may undergo indefinite proliferation and differentiate into different types of tissues depending on the treatment conditions ${ }^{86}$. Multipotent stem cells, however, may be obtained from tissue-derived pre- cursors (umbilical cord blood, bone marrow, adipose tissue, placenta, or blood), which are already grown tissues. Multipotent stem cells have only lineage-committed differentiation potential and may produce some cell types found within the

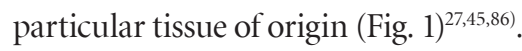

Of these stem cell types, iPSCs are derived from somatic cells by gene transfer in the presence of reprogramming factors. iPSCs face less ethical controversies than ESCs and are available for the development of new clinical applications and extending stem cell research to clinical setting ${ }^{43,66,76,78)}$. Scientific investigations involving iPSCs in developmental biology, pharmaco-toxicology, and molecular biology have been accel-

- Received : December 7, 2018 •Revised : March 16, 2019 •Accepted : April 22, 2019

- Address for reprints : Sang-Dae Kim

Department of Neurosurgery, Korea University Ansan Hospital, 123 Jeokgeum-ro, Danwon-gu, Ansan 15355, Korea

Tel : +82-31-412-5050, Fax : +82-31-412-5054, E-mail : neuron19@korea.ac.kr, ORCID : https://orcid.org/0000-0002-1519-9687

This is an Open Access article distributed under the terms of the Creative Commons Attribution Non-Commercial License (http://creativecommons.org/licenses/by-nc/4.0) which permits unrestricted non-commercial use, distribution, and reproduction in any medium, provided the original work is properly cited. 
erated by novel technologies aimed specifically to improve iPSC generation, growth, modification, and monitoring $^{3,10,74,77)}$. At present, PSCs research has rapidly evolved to offer the possibility of replacing regenerated and non-regenerated tissues, including the heart, pancreas, and brain, and provide various cell type ${ }^{37,90,96,97)}$. In particular, the field of regenerative neuroscience is very active and has already reached a clinical trial stages ${ }^{24,37,53,63,94)}$. The following sections discuss the main stem cell types and sources used in research and clinical trials along with their applications.

\section{CELL TYPES AND SOURCES}

\section{Human ESCs}

Human ESCs are self-renewing pluripotent cells, and may produce cells from the three germ layers. These cells are derived from the donated embryos either from in vitro fertilization procedure or created by somatic cell nuclear transfer technique (Table 1). ESCs or the cells of the embryo that have not undergone modification for less than 14 days are called "omnipotent cells" or "pluripotent cells" owing to their ability to differentiate into all cell and tissue types that make up the
ESCS

Isolate cells from ICM

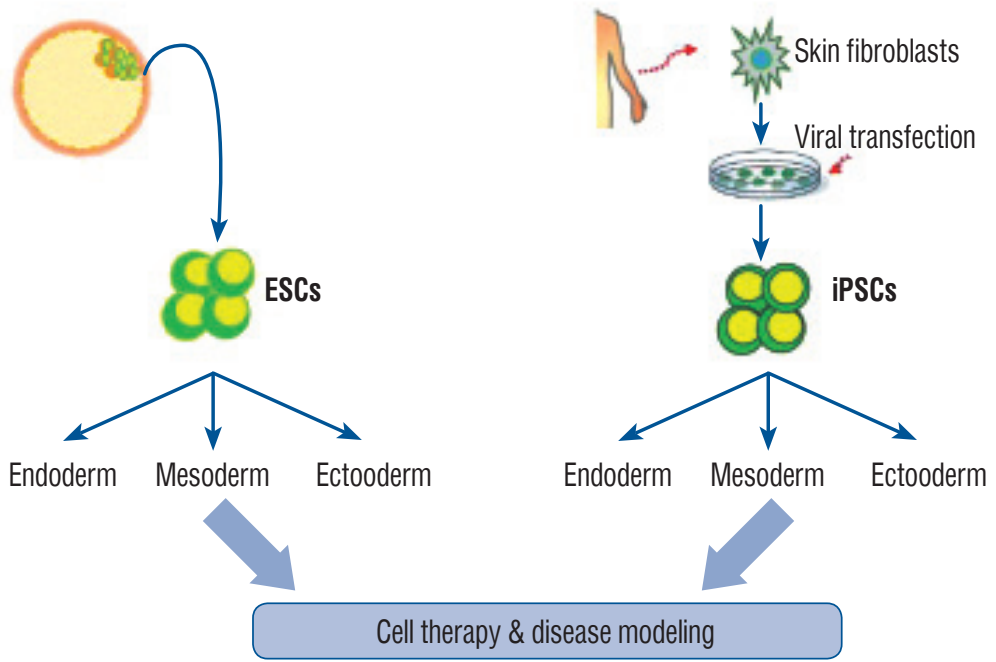

ASCs

Tissue-derived circulating precursors

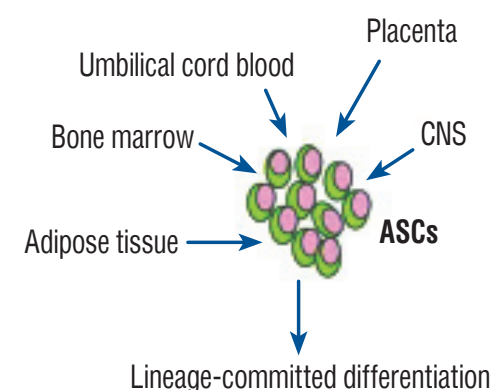

Enhanced perfusion and tissue function; supports cell therapy $\rightarrow$ paracrine effects

Fig. 1. Isolation and characterization of pluripotent stem cells. ESC : embryonic stem cell, ICM : inner cell mass, iPSC : induced pluripotent stem cell, ASC : adult stem cell, CNS : central nervous system.

Table 1. Type of stem cells based on their differentiation capacities

\begin{tabular}{|c|c|c|c|c|}
\hline Differentiation capacity & Isolated cells & Origins \& methods & Advantages & Disadvantages \\
\hline \multirow[t]{2}{*}{ Pluripotency } & ESCS & $\begin{array}{l}\text { 1. Blastocyst; inner cell mass } \\
\text { 2. Somatic cell nuclear } \\
\text { transfer (SCNT) }\end{array}$ & $\begin{array}{l}\text { - Differentiation into three germ } \\
\text { layers } \\
\text { - Self-renewal and high replication } \\
\text { - Approved by US FDA }\end{array}$ & $\begin{array}{l}\text { - Immunological concerns } \\
\text { - Ethical debate } \\
\text { - Potential for teratoma }\end{array}$ \\
\hline & iPSCs & $\begin{array}{l}\text { Reprogramming of somatic } \\
\text { cells by gene transfer }\end{array}$ & $\begin{array}{l}\text { - Less ethical concerns than ESCs } \\
\text { - Patient-specific } \\
\text { - Autologus }\end{array}$ & $\begin{array}{l}\text { - Need method standardization } \\
\text { - Potential for teratoma } \\
\text { - Validation for safety }\end{array}$ \\
\hline Multipotency & ASCS & $\begin{array}{l}\text { Bone marrow, adipose tissue, } \\
\text { umblical cord, amniotic } \\
\text { fluid, placenta, CNS }\end{array}$ & $\begin{array}{l}\text { - Less ethical concerns than ESCs } \\
\text { and IPSCs }\end{array}$ & $\begin{array}{l}\text { - Less cell proliferation } \\
\text { - Limit differentiation potencial }\end{array}$ \\
\hline
\end{tabular}

ESCs : embryonic stem cells, US FDA : United States Food and Drug Administration, iPSCs : induced pluripotent stem cells, ASCs : adult stem cells, CNS : central nervous system 
human body. In other words, these cells have the infinite ability to differentiate into all types of cells of the body ${ }^{45,81,86)}$.

Prior to 1998, scientists encountered difficulties in the isolation and cultivation of stem cells, as these cells present very short time during embryonic development and require special devices for their isolation from embryos. In 1998, however, a team of researchers led by Dr. James Thomson at the University of Wisconsin succeeded in isolating cells from the inner cell mass of blastocyst and cultivating human ESCs in a dish ${ }^{81)}$. Therefore, ESCs have greatly contributed to developmental biology and medicine. For instance, ESCs have facilitated the development of insulin-producing cells to treat diabetes $^{96,98)}$ or generation of neurons that can restore the function of patients paralyzed with spinal cord injuries ${ }^{16,20)}$. Many groups have demonstrated successful transplantation, survival, and differentiation of ESCs into neural cells in rodent models ${ }^{8,13,18,93)}$. In 2010, human ESC-derived oligodendrocyte progenitors were generated by Geron Corporation and a first-ever clinical trial involving patients with spinal cord injury (SCI) was performed ${ }^{2,75)}$. Advanced Cell Technology also reported a clinical trial using human ESC-derived retinal pigment epithelium to treat dry age-related macular degeneration in 2012 $2^{72)}$. Despite these advantages, embryonic cells obtained from the fusion of sperm and egg may cause severe immune rejection when used in patient with DNA from allogenic embryonic cells which was not autologus ${ }^{5,12)}$. In addition, the use of human embryos may encounter ethical issues, which limit research and clinical applications. Therefore, it is necessary to develop new pluripotent cells that circumvent ethical or immunological problems ${ }^{45,86)}$.

\section{ASCs}

ASCs are tissue-specific stem cells characterized with tissuerestricted differentiation. These cells have multipotency characteristics but lose pluripotency. ASCs are derived from the umbilical cord blood, bone marrow, adipose tissue, placenta, blood, or brain without direct use of embryo. These are primitive cells isolated just before undergoing differentiation into specific organs such as the bone, fat, cartilage, neuron, and blood. These include hematopoietic stem cells (HSCs), mesenchymal stem cells (MSCs), and neural stem cells (NSCs), all of which have become an important source for regenerative medicine ${ }^{27,45)}$.

The umbilical cord blood and bone marrow contain large number of HSCs and MSCs, including stromal cells. Adipose tissue is a source of MSCs, which have the potential to differentiate into blood cells, bone, fat, and cartilage ${ }^{17,30)}$. NSCs may be obtained from several regions of the fetal, postnatal, and adult central nervous system, including the subventricular zone of the brain and the spinal cord that may contain precursors for neurons, oligodendrocytes, and astrocytes ${ }^{38,46,64)}$.

ASCs have been extensively studied and are being tested in clinical trials for various diseases, including $\mathrm{SCI}^{16,17,30)}$. One of the important functions of ASCs is their anti-inflammatory and immunomodulatory effects and their ability to secret several neurotrophic factors; hence, ASCs may provide trophic support for endogenous and co-implanted cells ${ }^{7,14,15,47)}$. In addition, ASCs offer the advantage of avoiding less ethical debate than ESCs because these cells are isolated from the alreadygrown body tissues. However, ASCs tend to be difficult to proliferate and differentiate; hence, obtaining a desired cell shape or sufficient number of cells may be challenging ${ }^{17,27,30)}$.

\section{iPSCs}

iPSCs were first developed by Yamanaka in 2006 using mice $^{78)}$; human iPSCs were subsequently established in $2007^{76)}$. Since then, other researchers have developed human iPSCs and confirmed the reproducibility of the Yamanaka's research technique, a globally approved technology ${ }^{42,44,58,92)}$. iPSCs are derived from somatic cells of the adult body through the expression of specific exogenous genes or proteins and resemble ESCs morphologically, antigenically, and phenotypically in many ways. iPSCs have the following similarities as compared to ESCs derived from blastocysts ${ }^{45,74,77,86)}: 1$ ) the shape of the cell (round shape, large nucleus, and phosphorus, little cytoplasm) and the speed of growth are similar. 2) Gene expression and chromatin modification patterns are similar. 3) It may form teratoma in immunodeficient mice. 4) It produces chimera mouse upon insertion into a mouse blastocyst. And 5) germ line transmission of genes is possible.

Unlike ESCs, iPSCs have been generated from the tissues with somatic cells, such as the skin, dental tissue, peripheral blood, and urine. Thus, generation of iPSCs showed less ethical problems than ESCs and offers the advantage of customized treatment using the somatic cells of the patient with characteristics same as ESCs ${ }^{9,19,25,80,82,90)}$.

Yamanaka's team successfully induced pluripotency in adult somatic cells using four retrovirally transfected tran- 


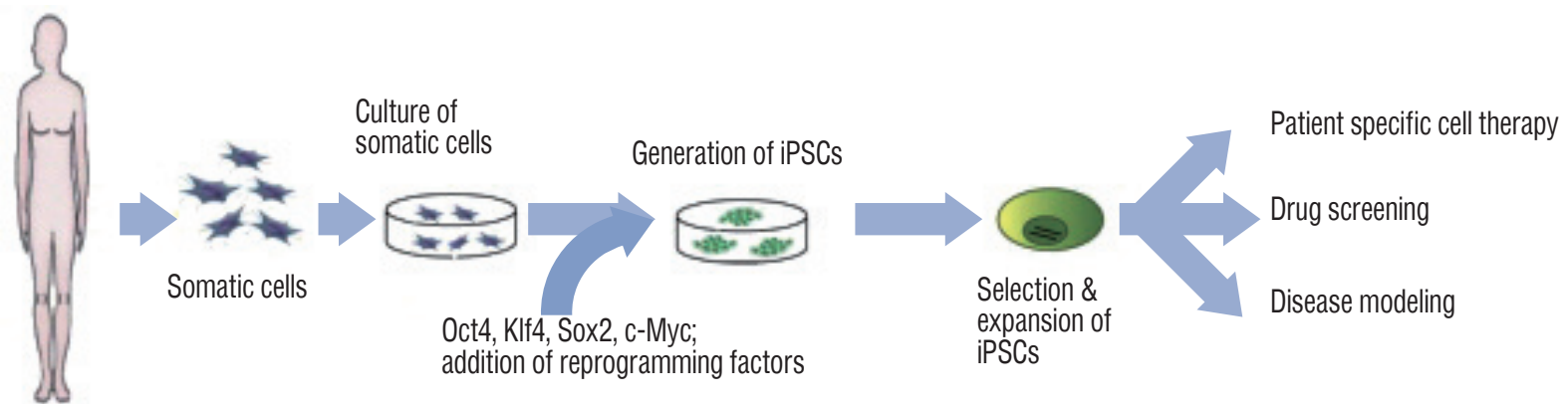

Fig. 2. Generation and applications of iPSCs from somatic cells. iPSCs can be applied in the field of clinical research for 1) patient-specific cell therapy, 2) drug screening, and 3) disease modeling. iPSC : induced pluripotent stem cell, Oct4 : octamer-binding transcription factor 4, KIf4 : Krüppel-like factor 4, Sox2 : SRY-box containing gene 2, c-Myc : cytoplasmic Myc gene.

scription factors, namely, Octamer $3 / 4$ (Oct3/4), SRY-box containing gene 2 (Sox2), Krüppel-like factor 4 (Klf4), and the protooncogene cytoplasmic Myc protein (c-Myc), in fibroblasts (Fig. 2) ${ }^{76,78)}$. However, the retroviral infection technology that delivers each of the "Yamanaka factors" (Oct3/4, Sox2, Klf4, and c-Myc; reprogramming factors; first generation method) has two disadvantages for clinical applications. First, genomic integration of reprogramming factors may lead to unwanted effects such as tumorigenesis ${ }^{5,25,55)}$. Second, this technology may lead to impairment of pluripotency. Reprogramming factors are required to establish pluripotency, but continual activation of exogenous reprogramming factors may decrease the differentiation capacity into specific cell types or transform cells altogether ${ }^{44,922}$.

Therefore, alternative induction methods have been introduced to avoid direct alterations of host cell DNA. The pluripotency genes either remain separate from the host genome or may be completely removable ${ }^{21,80}$. For instance, to involve the transient expression of reprogramming factors or virus-free, using adenoviruses ${ }^{99)}$, plasmids ${ }^{54}$, minicircle vectors ${ }^{50)}$, episomal vectors ${ }^{61,91)}$, Sendai viruses ${ }^{29,87)}$, synthetic mRNAs ${ }^{84)}$ or recombinant proteins ${ }^{95)}$ were developed (Fig. 3). iPSC reprogramming technology has been recently introduced to improve safety and increase efficiency through chemical approaches with small molecules ${ }^{39,41}$. This new generation protocol may help achieve more controllable reprogramming than that induced by transcription factors. These advancements have enabled the use of iPSCs for therapeutic purpos$\mathrm{es}^{9,40,43,63,90)}$.

Many research groups have studied the differentiation potential of iPSCs into three germ layers in humans for clinical applications ${ }^{3,11,37,90,96)}$. Human iPSCs use the same transcrip-

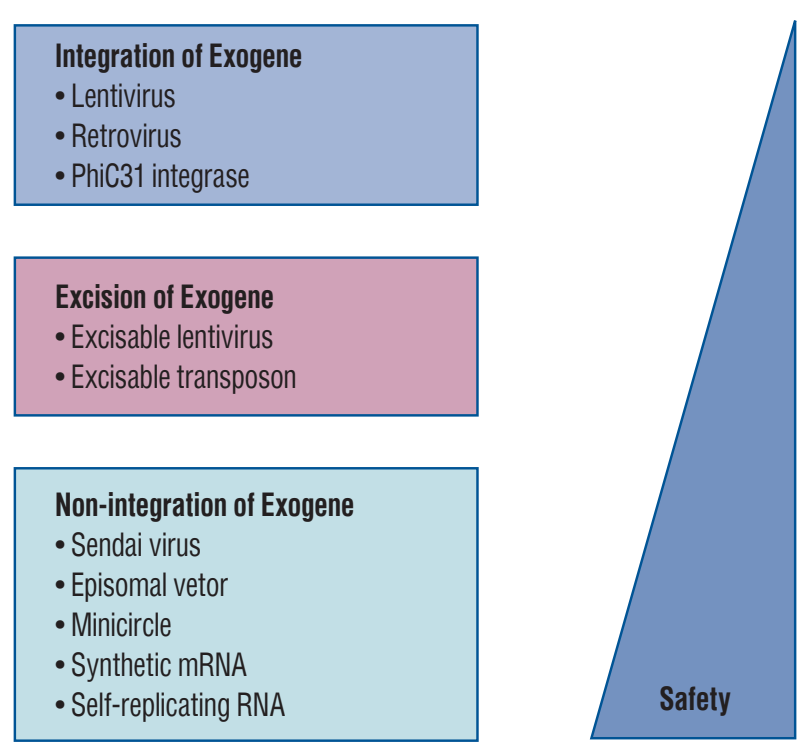

Fig. 3. Safety of cell reprogramming technologies.

tion network as ESCs, with similar early cell fate control mechanisms ${ }^{45,86)}$. For clinical applications, many specific lineage-committed cell types are required for cell therapy; these may be generated through good manufacturing practice conditions ${ }^{82}$. The production of specific cell subtypes for therapy may necessitate specific culture conditions. These differences between the trophic responses in vitro and in vivo pose major challenges to the clinical translation of preclinical iPSC studies $^{43,66,74)}$.

iPSCs may be used for the following applications : 1) development of disease-specific autologous cell therapy, 2) disease models to evaluate underlying mechanisms, and 3) drug screening and toxicity test $\mathrm{s}^{33,43,53,66,74,97)}$. However, as the history of iPSC research is short, the studies must be adequately verified to confirm the safe application of these cells for cell thera- 
py. In addition, human iPSCs derived from the somatic tissue of living donors and human tissue harvesting require extensive ethical and legal considerations regarding the dissemination of results and potential commercial benefit to donors for clinical translation ${ }^{53,97)}$; hence, standard regulations and policies need to be established.

\section{THERAPEUTIC POTENTIAL OF INDUCED PLU- RIPOTENT STEM CELLS IN NEUROLOGIC DIS- EASES}

The use of iPSCs for clinical applications requires the avoidance of genetic vectors or transgenes, which pose unknown risks in humans. In recent years, commercial stem cell research laboratories focus on using Sendai virus or episomal reprogramming instead of transgenes ${ }^{29,61,87,89,91)}$. Several different sources and types of cells have been extensively evaluated in basic science and at preclinical stage for neurologic diseas$\mathrm{es}^{1,23,49,52,63,67,94)}$. Dopaminergic neurons derived from non-human primate iPSCs have been successfully used to cure Parkinson's disease ${ }^{24)}$. The generation of iPSC models from familial cases of Parkinson's disease has greatly contributed to defining several molecular mechanisms related to disease progression $^{68,69)}$. Another example is stem cell transplantation for SCI that offers promising therapeutic strategies to address the multifactorial nature of SCI ${ }^{34,49,52,67,73,88)}$. Transplanted neurospheres from human iPSCs into SCI mouse models were successful and showed no tumorigenesis ${ }^{49,52)}$. In addition, safe and effective engraftment of human iPSC-derived neural progenitor cells for SCI therapy has been confirmed in non-human primates $^{34)}$. In patients with Alzheimer's disease, new potential diagnostic and therapeutic targets may be identified through the generation of iPSCs derived from patients with sporadic or familial Alzheimer's disease (AD) ${ }^{19,28,36,62,85)}$. Therefore, it may be important to evaluate the pathophysiology of AD and therapeutic effects of patient-derived iPSCs in the original patient. Generation of iPSCs from patients with neurologic diseases and their subsequent differentiation into neural lineages support the important information about molecular alterations in diseases and pave the way to potentially use these cells for regenerative medicine ${ }^{63)}$.

\section{COMBINATION WITH NEW CULTURE TECHNOL- OGIES FOR CELL THERAPY}

Advances in stem cell technology allow ESCs and iPSCs to exhibit unlimited proliferation properties, and the resulting cell differentiation reflects key structural and functional properties of organs such as the kidney, lung, gut, brain, and heart ${ }^{26,37,48,56)}$. During development, cell morphology and physiology undergo changes in terms of a wide variety of factors, and the culture environment plays a fundamental role in the growth of cells in cultures. Researchers started with twodimensional (2D) approach by growing sheets of cells, but the use of three dimensional (3D) techniques or nano-topography ${ }^{31,59)}$ such as culturing cells on 3D scaffolds (organoids) or Nano-Petri dishes is now common. 3D culture techniques with stem cells may provide various different type of organoids, and highlight information on the pathophysiology of diseases and the possible implications of therapy in clinical setting ${ }^{23,40,57)}$. In particular, organoid tissue culture may serve as a useful tool for modeling neurodevelopmental disorders such as microencephaly related with the exposure of Zika virus $^{65,79)}$, as would nanopatterned scaffolds for neural tissue engineering ${ }^{60)}$. Recent progress in stem cell biology, combined with basic knowledge of brain development, has led to a 3D culture method that recapitulates brain development in vitro. Human PSCs-derived 3D structures, referred to as 'brain organoids', have the potential to shed light on key aspects of development, moreover, patient-derived brain organoid may predict drug response in a personalized fashion ${ }^{71}$. As a new technology, 3D bioprinting allows creation of a precisely controlled 3D tissue or organ through evaluation of cell localization with biomolecules that are almost similar to tissue-specific extracellular microenvironment ${ }^{22,32)}$. Thus, the synergism of stem cell biology and 3D-biomaterial technology being influential in iPSC-based research and translation. Recent advances in bio-inks, printable hydrogels that encapsulate living cells, have improved the outcome of 3D tissue/organ printing constructs. For instance, 3D bio-printed cardiac patches, articular bones and cartilages, or glioma cell-laden scaffolds have been developed ${ }^{4,11,83)}$. Therefore, the combination of 3D scaffolds with 3D bio-printing technologies may support the appropriate cellular microenvironment, including cell survival and proliferation, and integrate well into the host tissue. However, applications of 3D bioprinting include the generation of 
multilayered skin, bone, vascular grafts, heart valves need to be improved with respect to the mechanical strength and integrity in the manufactured constructs. A better understanding of the tissue/organ microenvironment, which consists of multiple types of cells, is imperative for successful 3D bioprinting. These approaches may serve as a major contributing factor for the regeneration or restoration of tissues/organs. The many potential applications of these techniques are only at the beginning of the exploration. Safe iPSC-derived 3D bio-printed tissues/organs will be soon constructed and used for cell therapy ${ }^{23,56)}$.

\section{CONCLUSION}

Regenerative medicine using human PSCs is at the peak of development and the expectations for the use of PSCs to treat incurable diseases are high. iPSC research has rapidly progressed and reached clinical applications, while the outcomes are expected to meet the requirement in the near future. The possibility of using iPSCs in regenerative medicine may circumvent the ethical problems associated with ESC usage; however, ESCs and iPSCs exhibit a common problem : prevention of tumor development that may occur in response to the complete differentiation of stem cells before transplantation. There is a risk of tumor development in this process and incidence of cancer has been reported in an animal experiment ${ }^{25,53,55)}$. However, attempts have been directed to overcome this issue, and researchers have employed small molecule materials, protein preparations, or viral integration-free iPSCs to create stable iP$\mathrm{SCs}^{29,50,61,84,87,91,95)}$. These solutions may play key roles in the commercialization of methods involving de-differentiation induction. There are many discussions on the standardization of PSCs for research and therapy ${ }^{12,21,63)}$, including cell line derivation, registries, characterization, storage, banking, distribution, and cell engineering ${ }^{6,35,51,70)}$. Therefore, the safety associated with the use of iPSCs needs to be continuously evaluated.

Efforts have been directed to treat rare and incurable diseases, and clinical research and treatment using stem cells have recently been extended to strengthen national strategic investment in advanced countries. It is also actively promoting the marketability of stem cell therapy drugs. Overcoming issues such as limited commercialization, inconsistent largescale production, and safety issues of human iPSCs may allow researchers to provide a truly viable alternative cell therapy source. It would be possible to manage different pharmacological and genetic approaches that may provide new therapeutic strategies. In addition, patient-specific, disease-related cells may serve as an incredibly powerful tool for studying disease mechanisms through functional analysis, genetic alterations, and in vitro drug screening.

\section{CONFLICTS OF INTEREST}

No potential conflict of interest relevant to this article was reported.

\section{INFORMED CONSENT}

This type of study does not require informed consent.

\section{AUTHOR CONTRIBUTIONS}

\author{
Conceptualization : EAC, SDK \\ Data curation : EAC, MHN \\ Formal analysis : SWJ \\ Funding acquisition : SDK \\ Methodology : EAC, SWJ \\ Project administration : EAC, SWJ, MHN, SDK \\ Visualization : MHN, SDK \\ Writing - original draft : EAC \\ Writing - review \& editing : EAC, SDK
}

\section{- Acknowledgements}

This research was supported by the Korea University Medical Center (K1613701).

\section{References}

1. Abud EM, Ramirez RN, Martinez ES, Healy LM, Nguyen CHHH, Newman SA, et al. : iPSC-derived human microglia-like cells to study neurological diseases. Neuron 94 : 278-293.e9, 2017

2. Alper $\mathrm{J}$ : Geron gets green light for human trial of ES cell-derived product. Nat Biotechnol 27 : 213-214, 2009 
3. Assawachananont J, Mandai M, Okamoto S, Yamada C, Eiraku M, Yonemura $S$, et al. : Transplantation of embryonic and induced pluripotent stem cell-derived 3D retinal sheets into retinal degenerative mice. Stem Cell Reports 2 : 662-674, 2014

4. Bejleri D, Streeter BW, Nachlas ALY, Brown ME, Gaetani R, Christman $\mathrm{KL}$, et al. : A bioprinted cardiac patch composed of cardiac-specific extracellular matrix and progenitor cells for heart repair. Adv Heathc Mater 7 : e1800672, 2018

5. Charron D, Suberbielle-Boissel C, Al-Daccak R : Immunogenicity and allogenicity: a challenge of stem cell therapy. J Cardiovasc Transl Res 2 : 130-138, 2009

6. Chen KG, Mallon BS, McKay RD, Robey PG : Human pluripotent stem cell culture: considerations for maintenance, expansion, and therapeutics. Cell Stem Cell 14 : 13-26, 2014

7. Chen N, Kamath S, Newcomb J, Hudson J, Garbuzova-Davis S, Bickford $P$, et al. : Trophic factor induction of human umbilical cord blood cells in vitro and in vivo. J Neural Eng $4:$ 130-145, 2007

8. Cohen MA, Itsykson P, Reubinoff BE : Neural differentiation of human ES cells. Curr Protoc Cell Biol Chapter 23 : Unit 23.7, 2007

9. Cramer AO, MacLaren RE : Translating induced pluripotent stem cells from bench to bedside: application to retinal diseases. Curr Gene Ther 13 : 139-151, 2013

10 Crespo M, Vilar E, Tsai SY, Chang K, Amin S, Srinivasan T, et al. : Colonic organoids derived from human induced pluripotent stem cells for modeling colorectal cancer and drug testing. Nat Med 23 : 878-884, 2017

11. Dhawan A, Kennedy PM, Rizk EB, Ozbolat IT : Three-dimensional bioprinting for bone and cartilage restoration in orthopaedic surgery. J Am Acad Orthop Surg 27 : e215-e226, 2019

12. Drukker $M$, Benvenisty $N$ : The immunogenicity of human embryonic stem-derived cells. Trends Biotechnol 22 : 136-141, 2004

13. Duncan ID : Oligodendrocytes and stem cell transplantation: their potential in the treatment of leukoencephalopathies. J Inherit Metab Dis 28 : 357-368, 2005

14. Enciso J, Mayani H, Mendoza L, Pelayo R : Modeling the pro-inflammatory tumor microenvironment in acute lymphoblastic leukemia predicts a breakdown of hematopoietic-mesenchymal communication networks. Front Physiol 7 : 349, 2016

15. Fajardo-Orduña GR, Mayani H, Montesinos JJ : Hematopoietic support capacity of mesenchymal stem cells: biology and clinical potential. Arch Med Res 46 : 589-596, 2015

16. Fehlings $M G$, Vawda $R$ : Cellular treatments for spinal cord injury: the time is right for clinical trials. Neurotherapeutics 8 : 704-720, 2011

17. Flores-Guzmán $P$, Fernández-Sánchez $V$, Mayani $H$ : Concise review: ex vivo expansion of cord blood-derived hematopoietic stem and progenitor cells: basic principles, experimental approaches, and impact in regenerative medicine. Stem Cells Transl Med 2 : 830-838, 2013

18. Fluckiger AC, Dehay C, Savatier $P$ : Embryonic stem cells and cell replacement therapies in the nervous system. Med Sci (Paris) 19 : 699708, 2003

19. Freude K, Pires C, Hyttel P, Hall VJ : Induced pluripotent stem cells derived from Alzheimer's disease patients: the promise, the hope and the path ahead. J Clin Med 3 : 1402-1436, 2014

20. Gensel JC, Donnelly DJ, Popovich PG : Spinal cord injury therapies in humans: an overview of current clinical trials and their potential effects on intrinsic CNS macrophages. Expert Opin Ther Targets 15 : 505-518, 2011

21. Goh PA, Caxaria S, Casper C, Rosales C, Warner TT, Coffey PJ, et al. : A systematic evaluation of integration free reprogramming methods for deriving clinically relevant patient specific induced pluripotent stem (iPS) cells. PLoS One 8 : e81622, 2013

22. Gu BK, Choi DJ, Park SJ, Kim YJ, Kim CH : 3D bioprinting technologies for tissue engineering applications. Adv Exp Med Biol 1078 : 15-28, 2018

23. Gu Q, Tomaskovic-Crook E, Wallace GG, Crook JM : 3D Bioprinting human induced pluripotent stem cell constructs for in situ cell proliferation and successive multilineage differentiation. Adv Heathc Mater 6 : 1700175, 2017

24. Hallett PJ, Deleidi M, Astradsson A, Smith GA, Cooper O, Osborn TM, et al. : Successful function of autologous iPSC-derived dopamine neurons following transplantation in a non-human primate model of Parkinson's disease. Cell Stem Cell 16 : 269-274, 2015

25. Hanna JH, Saha K, Jaenisch R : Pluripotency and cellular reprogramming: facts, hypotheses, unresolved issues. Cell 143 : 508-525, 2010

26. Ho BX, Pek NMQ, Soh BS : Disease modeling using 3D organoids derived from human induced pluripotent stem cells. Int J Mol Sci 19 : 936, 2018

27. Isobe Y, Koyama N, Nakao K, Osawa K, Ikeno M, Yamanaka S, et al. : Comparison of human mesenchymal stem cells derived from bone marrow, synovial fluid, adult dental pulp, and exfoliated deciduous tooth pulp. Int J Oral Maxillofac Surg 45 : 124-131, 2016

28. Israel MA, Yuan SH, Bardy C, Reyna SM, Mu Y, Herrera C, et al. : Probing sporadic and familial Alzheimer's disease using induced pluripotent stem cells. Nature 482 : 216-220, 2012

29. Kawagoe S, Higuchi T, Otaka M, Shimada Y, Kobayashi H, Ida H, et al. : Morphological features of iPS cells generated from Fabry disease skin fibroblasts using Sendai virus vector (SeVdp). Mol Genet Metab 109 : 386-389, 2013

30. Kfoury $Y$, Scadden DT : Mesenchymal cell contributions to the stem cell niche. Cell Stem Cell $16:$ 239-253, 2015

31. Kim JH, Kim HW, Cha KJ, Han J, Jang YJ, Kim DS, et al. : Nanotopography promotes pancreatic differentiation of human embryonic stem cells and induced pluripotent stem cells. ACS Nano 10 : 3342-3355, 2016

32. Kim SJ, Park J, Byun H, Park YW, Major LG, Lee DY, et al. : Hydrogels with an embossed surface: an all-in-one platform for mass production and culture of human adipose-derived stem cell spheroids. Biomaterials 188 : 198-212, 2019

33. Kiskinis E, Eggan $\mathrm{K}$ : Progress toward the clinical application of patientspecific pluripotent stem cells. J Clin Invest 120 : 51-59, 2010

34. Kobayashi Y, Okada Y, Itakura G, Iwah H, Nishimura S, Yasuda A, et al. : Pre-evaluated safe human iPSC-derived neural stem cells promote functional recovery after spinal cord injury in common marmoset without tumorigenicity. PLoS One 7 : e52787, 2012 
35. Konagaya S, Ando T, Yamauchi T, Suemori H, Iwata H : Long-term maintenance of human induced pluripotent stem cells by automated cell culture system. Sci Rep 5 : 16647, 2015

36. Kondo T, Asai M, Tsukita K, Kutoku Y, Ohsawa Y, Sunada Y, et al. : Modeling Alzheimer's disease with iPSCs reveals stress phenotypes associated with intracellular Abeta and differential drug responsiveness. Cell Stem Cell $12:$ 487-496, 2013

37. Lancaster MA, Renner M, Martin CA, Wenzel D, Bicknell LS, Hurles ME, et al. : Cerebral organoids model human brain development and microcephaly. Nature $501:$ 373-379, 2013

38. Levison SW, Druckman SK, Young GM, Basu A : Neural stem cells in the subventricular zone are a source of astrocytes and oligodendrocytes, but not microglia. Dev Neurosci 25 : 184-196, 2003

39. Li W, Li K, Wei W, Ding S: Chemical approaches to stem cell biology and therapeutics. Cell Stem Cell $13: 270-283,2013$

40. Liu C, Oikonomopoulos A, Sayed N, Wu JC : Modeling human diseases with induced pluripotent stem cells: from 2D to 3D and beyond. Development 145 : dev156166, 2018

41. Liu K, Yu C, Xie M, Li K, Ding S: Chemical modulation of cell fate in stem cell therapeutics and regenerative medicine. Cell Chem Biol 23 : 893-916, 2016

42. Maherali N, Sridharan R, Xie W, Utikal J, Eminli S, Arnold K, et al. : Directly reprogrammed fibroblasts show global epigenetic remodeling and widespread tissue contribution. Cell Stem Cell 1 : 55-70, 2007

43. Marx V. Stem cells: disease models that show and tell. Nat Methods 12 : 111-114, 2015

44. Meissner A, Wernig $M$, Jaenisch $R$ : Direct reprogramming of genetically unmodified fibroblasts into pluripotent stem cells. Nat Biotechnol 25 : 1177-1181, 2007

45. Melton D : 'Stemness': Definitions, Criteria, and Standards in Lanza R, Atala A (eds) : Essentials of Stem Cell Biology, ed 3. London : Elsevier, 2014, pp7-17

46. Messina DJ, Alder L, Tresco PA : Comparison of pure and mixed populations of human fetal-derived neural progenitors transplanted into intact adult rat brain. Exp Neurol 184 : 816-829, 2003

47. Montesinos JJ, Mora-García Mde L, Mayani H, Flores-Figueroa E, GarcíaRocha R, Fajardo-Orduña GR, et al. : In vitro evidence of the presence of mesenchymal stromal cells in cervical cancer and their role in protecting cancer cells from cytotoxic T cell activity. Stem Cells Dev 22 : 25082519, 2013

48. Montgomery A, Wong A, Gabers N, Willerth SM : Engineering personalized neural tissue by combining induced pluripotent stem cells with fibrin scaffolds. Biomater Sci 3 : 401-413, 2015

49. Nakamura $\mathrm{M}, \mathrm{Okano} \mathrm{H}$ : Cell transplantation therapies for spinal cord injury focusing on induced pluripotent stem cells. Cell Res 23 : 70-80, 2013

50. Narsinh KH, Jia F, Robbins RC, Kay MA, Longaker MT, Wu JC : Generation of adult human induced pluripotent stem cells using nonviral minicircle DNA vectors. Nat Protoc 6 : 78-88, 2011

51. Nestor MW, Noggle SA : Standardization of human stem cell pluripotency using bioinformatics. Stem Cell Res Ther $4: 37,2013$
52. Nori S, Okada Y, Yasuda A, Tsuji O, Takashashi Y, Kobayashi Y, et al. : Grafted human-induced pluripotent stem-cell-derived neurospheres promote motor functional recovery after spinal cord injury in mice. Proc Natl Acad Sci U S A 108 : 16825-16830, 2011

53. Okano H, Nakamura M, Yoshida K, Okada Y, Tsuji O, Nori S, et al. : Steps toward safe cell therapy using induced pluripotent stem cells. Circ Res 112 : 523-533, 2013

54. Okita K, Hong H, Takahashi K, Yamanaka S : Generation of mouseinduced pluripotent stem cells with plasmid vectors. Nat Protoc 5 : 418-428, 2010

55. Okita K, Ichisaka T, Yamanaka S: Generation of germline-competent induced pluripotent stem cells. Nature $448:$ 313-317, 2007

56. Ong CS, Fukunishi T, Nashed A, Blazeski A, Zhang H, Hardy S, et al. : Creation of cardiac tissue exhibiting mechanical integration of spheroids using 3D bioprinting. J Vis Exp (125) : e55438, 2017.

57. Ong CS, Yesantharao P, Huang CY, Mattson G, Boktor J, Fukunishi T, et al. : 3D bioprinting using stem cells. Pediatr Res 83 : 223-231, 2018

58. Park IH, Zhao R, West JA, Yabuuchi A, Huo H, Ince TA, et al. : Reprogramming of human somatic cells to pluripotency with defined factors. Nature 451 : 141-146, 2008

59. Park KS, Cha KJ, Han IB, Shin DA, Cho DW, Lee SH, et al. : Mass-producible nano-featured polystyrene surfaces for regulating the differentiation of human adipose-derived stem cells. Macromol Biosci 12 : 14801489, 2012

60. Park S, Kim D, Park S, Kim S, Lee D, Kim W, et al. : Nanopatterned scaffolds for neural tissue engineering and regenerative medicine. Adv Exp Med Biol 1078 : 421-443, 2018

61. Piao Y, Hung SS, Lim SY, Wong RC, Ko MS : Efficient generation of integration-free human induced pluripotent stem cells from keratinocytes by simple transfection of episomal vectors. Stem Cells Transl Med 3 : 787-791, 2014

62. Poon A, Li T, Pires C, Nielsen TT, Nielsen JE, Holst B, et al. : Derivation of induced pluripotent stem cells from a familial Alzheimer's disease patient carrying the L282F mutation in presenilin 1. Stem Cell Res $17: 470$ 473, 2016

63. Poon A, Zhang Y, Chandrasekaran A, Phanthong P, Schmid B, Nielsen TT, et al. : Modeling neurodegenerative diseases with patient-derived induced pluripotent cells: possibilities and challenges. N Biotechnol 39(Pt B) : 190-198, 2017

64. Poulsen FR, Meyer M, Rasmussen JZ : Generation of new nerve cells in the adult human brain. Ugeskr Laeger 165 : 1443-1447, 2003

65. Qian X, Nguyen HN, Song MM, Hadiono C, Ogden SC, Hammack C, et al. : Brain-region-specific organoids using mini-bioreactors for modeling ZIKV exposure. Cell $165:$ 1238-1254, 2016

66. Robinton DA, Daley GQ : The promise of induced pluripotent stem cells in research and therapy. Nature $481:$ 295-305, 2012

67. Rossi SL, Nistor G, Wyatt T, Yin HZ, Poole AJ, Weiss JH, et al. : Histological and functional benefit following transplantation of motor neuron progenitors to the injured rat spinal cord. PLoS One 5 : e11852, 2010

68. Sánchez-Danés A, Richaud-Patin Y, Carballo-Carbajal I, Jiménez-Delgado S, Caig C, Mora S, et al. : Disease-specific phenotypes in dopamine 
neurons from human iPS-based models of genetic and sporadic Parkinson's disease. EMBO Mol Med 4 : 380-395, 2012

69. Sanders LH, Laganière J, Cooper O, Mak SK, Vu BJ, Huang YA, et al. : LRRK2 mutations cause mitochondrial DNA damage in iPSC-derived neural cells from Parkinson's disease patients: reversal by gene correction. Neurobiol Dis 62 : 381-386, 2014

70. Sasaki K, Makiyama T, Yoshida Y, Wuriyanghai Y, Kamakura T, Nishiuchi $S$, et al. : Patient-specific human induced pluripotent stem cell model assessed with electrical pacing validates S107 as a potential therapeutic agent for catecholaminergic polymorphic ventricular tachycardia. PLoS One 11 : e0164795, 2016

71. Satpathy A, Datta P, Wu Y, Ayan B, Bayram E, Ozbolat IT. Developments with 3D bioprinting for novel drug discovery. Expert Opin Drug Discov 13 : 1115-1129, 2018

72. Schwartz SD, Hubschman JP, Heilwell G, Franco-Cardenas V, Pan CK, Ostrick RM, et al. : Embryonic stem cell trials for macular degeneration: a preliminary report. Lancet $379:$ 713-720, 2012

73. Sharp J, Frame J, Siegenthaler M, Nistor G, Keirstead HS : Human embryonic stem cell-derived oligodendrocyte progenitor cell transplants improve recovery after cervical spinal cord injury. Stem Cells 28 : 152163,2010

74. Soria-Valles C, López-Otín C : iPSCs: on the road to reprogramming aging. Trends Mol Med 22 : 713-724, 2016

75. Strauss $S:$ Geron trial resumes, but standards for stem cell trials remain elusive. Nat Biotechnol 28 : 989-990, 2010

76. Takahashi K, Tanabe K, Ohnuki M, Naritta M, Ichisaka T, Tomoda K, et al. : Induction of pluripotent stem cells from adult human fibroblasts by defined factors. Cell $131:$ :861-872, 2007

77. Takahashi K, Yamanaka $S:$ A decade of transcription factor-mediated reprogramming to pluripotency. Nat Rev Mol Cell Biol 17 : 183-193, 2016

78. Takahashi K, Yamanaka S : Induction of pluripotent stem cells from mouse embryonic and adult fibroblast cultures by defined factors. Cell $126: 663-676,2006$

79. Tang H, Hammack C, Ogden SC, Wen Z, Qian X, Li Y, et al. : Zika virus infects human cortical neural progenitors and attenuates their growth. Cell Stem Cell $18:$ 587-590, 2016

80. Telpalo-Carpio S, Aguilar-Yañez J, Gonzalez-Garza M, Cruz-Vega D, Moreno-Cuevas J : iPS cells generation: an overview of techniques and methods. J Stem Cells Regen Med 9 : 2-8, 2013

81. Thomson JA, Itskovitz-Eldor J, Shapiro SS, Waknitz MA, Swiergiel JJ, Marshall VS, et al. : Embryonic stem cell lines derived from human blastocysts. Science 282 : 1145-1147, 1998

82. Turner M, Leslie S, Martin NG, Peschanski M, Rao M, Taylor CJ, et al. : Toward the development of a global induced pluripotent stem cell library. Cell Stem Cell $13: 382-384,2013$

83. Wang $X$, Dai $X$, Zhang $X, M a ~ C, ~ L i ~ X, X u ~ T$, et al. : 3D bioprinted glioma cell-laden scaffolds enriching glioma stem cells via epithelial-mesenchy- mal transition. J Biomed Mater Res A 107 : 383-391, 2019

84. Warren L, Manos PD, Ahfeldt T, Loh YH, Li H, Lau F, et al. : Highly efficient reprogramming to pluripotency and directed differentiation of human cells with synthetic modified mRNA. Cell Stem Cell 7 : 618-630, 2010

85. Yagi T, Ito D, Okada Y, Akamatsu W, Nihei Y, Yoshizaki T, et al. : Modeling familial Alzheimer's disease with induced pluripotent stem cells. Hum Mol Genet 20 : 4530-4539, 2011

86. Yamanaka S, Li J, Kania G, Elliott S, Wersto RP, Van Eyk J, et al. : Pluripotency of embryonic stem cells. Cell Tissue Res $331: 5-22,2008$

87. Yang W, Mills JA, Sullivan S, Liu Y, French DL, Gadue P : iPSC Reprogramming from Human Peripheral Blood Using Sendai Virus Mediated Gene Transfer. Cambridge : StemBook, 2008

88. Yasuda A, Tsuji O, Shibata S, Nori S, Takano M, Kobayashi Y, et al. : Significance of remyelination by neural stem/progenitor cells transplanted into the injured spinal cord. Stem Cells 29 : 1983-1994, 2011

89. Ye $H$, Wang $Q$ : Efficient generation of non-integration and feeder-free induced pluripotent stem cells from human peripheral blood cells by Sendai virus. Cell Physiol Biochem 50 : 1318-1331, 2018

90. Yoshida Y, Yamanaka S: iPS cells: a source of cardiac regeneration. J Mol Cell Cardiol 50 : 327-332, 2011

91. Yu J, Hu K, Smuga-Otto K, Tian S, Stewart R, Slukvin II, et al. : Human induced pluripotent stem cells free of vector and transgene sequences. Science 324 : 797-801, 2009

92. Yu J, Vodyanik MA, Smuga-Otto K, Antosiewicz-Bourget J, Frane JL, Tian $\mathrm{S}$, et al. : Induced pluripotent stem cell lines derived from human somatic cells. Science 318 : 1917-1920, 2007

93. Zhang SC, Li XJ, Johnson MA, Pankratz MT : Human embryonic stem cells for brain repair? Philos Trans R Soc Lond B Biol Sci 363 : $87-$ 99, 2008

94. Zhang Y, Schmid B, Nikolaisen NK, Rasmussen MA, Aldana BI, Agger $M$, et al. : Patient iPSC-derived neurons for disease modeling of frontotemporal dementia with mutation in CHMP2B. Stem Cell Reports 8 : 648-658, 2017

95. Zhou H, Wu S, Joo JY, Zhu S, Han DW, Lin T, et al. : Generation of induced pluripotent stem cells using recombinant proteins. Cell Stem Cell $4: 381-384,2009$

96. Zhou Q, Brown J, Kanarek A, Rajagopal J, Melton DA : In vivo reprogramming of adult pancreatic exocrine cells to beta-cells. Nature 455 : 627-632, 2008

97. Zhou Q, Melton DA : Extreme makeover: converting one cell into another. Cell Stem Cell 3 : 382-388, 2008

98. Zhou Q, Melton DA : Pathways to new beta cells. Cold Spring Harb Symp Quant Biol 73 : 175-181, 2008

99. Zhou W, Freed $C R$ : Adenoviral gene delivery can reprogram human fibroblasts to induced pluripotent stem cells. Stem Cells 27 : 26672674,2009 